\title{
Single-cell Protein and Xylitol Production by a Novel Yeast Strain Candida intermedia FL023 from Lignocellulosic Hydrolysates and Xylose
}

\author{
Jiaqiang $\mathrm{Wu}^{1} \cdot$ Jinlong $\mathrm{Hu}^{1} \cdot$ Shumiao Zhao ${ }^{1}$ • \\ Mingxiong $\mathrm{He}^{2} \cdot$ Guoquan $\mathrm{Hu}^{2} \cdot$ Xiangyang $\mathrm{Ge}^{1}$. \\ Nan Peng ${ }^{1,2}$ (iD
}

Received: 18 September 2017 / Accepted: 19 October 2017 /

Published online: 2 November 2017

(C) The Author(s) 2017. This article is an open access publication

\begin{abstract}
Yeasts are good candidates to utilize the hydrolysates of lignocellulose, the most abundant bioresource, for bioproducts. This study aimed to evaluate the efficiencies of singlecell protein (SCP) and xylitol production by a novel yeast strain, Candida intermedia FL023, from lignocellulosic hydrolysates and xylose. This strain efficiently assimilated hexose, pentose, and cellubiose for cell mass production with the crude protein content of $484.2 \mathrm{~g} \mathrm{~kg}^{-1}$ dry cell mass. SCP was produced by strain FL023 using corncob hydrolysate and urea as the carbon and nitrogen sources with the dry cell mass productivity $0.86 \mathrm{~g} \mathrm{~L}^{-1} \mathrm{~h}^{-1}$ and the yield of $0.40 \mathrm{~g} \mathrm{~g}^{-1}$ sugar. SCP was also produced using $\mathrm{NaOH}$-pretreated Miscanthus sinensis straw and corn steep liquor as the carbon and nitrogen sources through simultaneous saccharification and fermentation with the dry cell productivity of $0.23 \mathrm{~g} \mathrm{~L}^{-1} \mathrm{~h}^{-1}$ and yield of $0.17 \mathrm{~g} \mathrm{~g}^{-1}$ straw. C. intermedia FL023 was tolerant to $0.5 \mathrm{~g} \mathrm{~L}^{-1}$ furfural, acetic acid, and syringaldehyde in xylitol fermentation and produced $45.7 \mathrm{~g} \mathrm{~L}^{-1}$ xylitol from xylose with the productivity of $0.38 \mathrm{~g} \mathrm{~L}^{-1} \mathrm{~h}^{-1}$ and the yield of $0.57 \mathrm{~g} \mathrm{~g}^{-1}$ xylose. This study provides feasible methods for feed and food additive production from the abundant lignocellulosic bioresources.
\end{abstract}

Keywords Candida intermedia $\cdot$ Single-cell protein $\cdot$ Xylitol $\cdot$ Lignocellulosic hydrolysate · Simultaneous saccharification and fermentation

Nan Peng

nanp@mail.hzau.edu.cn

1 State Key Laboratory of Agricultural Microbiology, College of Life Science and Technology, Huazhong Agricultural University, Wuhan 430070, People's Republic of China

2 Key Laboratory of Development and Application of Rural Renewable Energy (Ministry of Agriculture), Biomass Energy Technology Research Centre, Biogas Institute of Ministry of Agriculture, Chengdu 610041 Sichuan, People's Republic of China 


\section{Introduction}

There is a growing interest in utilization of renewable bioresources for production of biochemicals (such as xylitol and lactic acid) and single-cell proteins (SCPs). Renewable bioresource provides cost-effective feedstock as it is the most abundant source of sugars and does not compete with food resources [29]. Potential renewable bioresource substrates include corncobs and stalks, sugarcane press mud, and Miscanthus straw; however, the deconstruction of cellulosic polymers through hydrolysis and saccharification requires additional processing that increases the cost and difficulty of lignocellulose-to-product conversion [18]. Xylose is the second most abundant sugar in lignocellulose after glucose [26]; therefore, efficient and rapid utilization of xylose is a prerequisite for biochemicals and SCP production.

The production of sufficient protein from livestock in Asia, particularly China, represents a serious challenge for the future. Food-producing animals rely heavily on soybean meal, fishmeal, and corn [3]. Increasing prices for the most important agricultural crops will lead to an increase in prices for beef, pork, and poultry [36]. Food scarcity may become even more serious in light of the rising demand for biofuels and subsequent reductions in agricultural productivity. Land and labor productivity grew at a substantially slower rate from 1990 to 2005 than from 1961 to 1990 [1]. SCP is a major protein substitute and its bioconversion from agricultural residues and industrial wastes makes it cheaper than traditional protein sources [2]. Algae, fungi, and bacteria are the chief sources of microbial protein that can be used as SCP. Many fungal species are used as protein-rich food, including the most common yeasts Candida, Hansenula, Pichia, Torulopsis, and Saccharomyces. Many other filamentous fungi also serve as sources of SCP [2]. Chaetomium cellulolyticum, a cellulolytic fungus, degrades lignocellulose via a secreted cellulase to produce SCP $[10,24,25]$. Chaetomium strains, however, with the exception of C. cellulolyticum, produce mycotoxins that are cytotoxic in HeLa cells [34]. Aspergillus terreus degrades alkali-pretreated sugarcane bagasse to produce SCP; optimum conditions yield a protein content of 210-280 $\mathrm{g} \mathrm{kg}^{-1}$ [7]. Candida tropicalis, C. langeronii, and C. arborea have been used with sugar cane bagasse and rice straw hydrolysate to produce SCP [27, 30, 42]. Productivities were 0.2 and $0.97 \mathrm{~g} \mathrm{~L}^{-1} \mathrm{~h}^{-1}$ and yields were 0.31 and $0.40 \mathrm{~g} \mathrm{~g}^{-1}$ for C. tropicalis and C. langeronii, respectively. Debaryomyces hansenii, Kluyveromyces marxianus, and Pichia stipitis assimilate non-detoxified hemicellulosic hydrolysate from spent brewery grains; D. hansenii showed the best performance with a productivity of $0.56 \mathrm{~g} \mathrm{~L}^{-1} \mathrm{~h}^{-1}$ [6].

Xylitol is categorized as a polyalcohol or sugar alcohol with a wide range of uses in medical and food industries. However, the traditional production method involves the reduction of D-xylose to xylitol via a catalytic chemical reaction with high pressure and temperature resulting in a complicated process, equipment, and large investment [23]. Biotechnological xylitol production is a potentially attractive replacement for the chemical process, as it occurs under much milder process conditions and can be based on sugar mixtures such as lignocellulosic hydrolysates to save on energy and substrate purification costs [15]. Biotechnological conversion is mostly accomplished by whole cell biocatalyst, involving bacteria, fungi, yeast and/or recombinant strains, or cell-free/immobilized enzyme system. Several challenges emerged in xylitol fermentation from lignocellulosic materials, most of them related to hydrolysis of biomass, detoxification, fermentation process factors, etc. For example, inhibitors, such as furfural, acetic acid, and syringaldehyde, generated from acid or alkaline pretreatments of lignocellulosic materials are toxic to microorganisms and inhibitory to cellulase, resulting in low fermentation efficiency [9, 22]. Therefore, isolating potential species with tolerance to inhibitors is important for xylitol production from lignocellulosic materials. 
Although efforts are being made to improve SCP and xylitol production from agricultural lignocellulose residues, an efficient and effective method has yet to be developed. In this study, we isolated a novel $C$. intermedia strain FL023 which was tolerant to furfural, acetic acid, and syringaldehyde, mimicking the main inhibitor from alkaline-pretreated lignocellulosic materials. C. intermedia FL023 utilized lignocellulosic hydrolysate for high-efficiency SCP production and utilized xylose for xylitol production. Taken together, this study provided potential methods for SCP and xylitol production from renewable bioresources.

\section{Materials and Methods}

\section{Screening for High-Efficiency Xylose-Utilization Yeast}

Six yeast strains were obtained from the Microbial Genetic Stock Centre (MGSC) of State Key Laboratory of Agricultural Microbiology, Wuhan, China. All strains were maintained on yeast extract peptone dextrose (YPD) agar tube slants (glucose $20 \mathrm{~g} \mathrm{~L}^{-1}$, peptone $20 \mathrm{~g} \mathrm{~L}^{-1}$, yeast extract $10 \mathrm{~g} \mathrm{~L}^{-1}$, and agar $20 \mathrm{~g} \mathrm{~L}^{-1}$ ). For screening, yeast strains were inoculated in YPD medium and cultured at $30{ }^{\circ} \mathrm{C}$ for $48 \mathrm{~h}$ with shaking. An aliquot $(0.5 \mathrm{~mL})$ of preculture was transferred into $50 \mathrm{~mL}$ yeast extract peptone xylose (YPX) medium (xylose $20 \mathrm{~g} \mathrm{~L}^{-1}$, peptone $5 \mathrm{~g} \mathrm{~L}^{-1}$, yeast extract $3 \mathrm{~g} \mathrm{~L}^{-1}$ ) and incubated at $30^{\circ} \mathrm{C}$ for $48 \mathrm{~h}$ with shaking. After incubation, viable cell counts were determined by standard plate counting, dry cell weight was measured, and cell mass yields were calculated. The yeast strain with the highest xylose-dry cell weight conversion efficiency was selected for further study. The growth curve of $C$. intermedia cells in YPD, YPX, YPC (20 $\mathrm{g} \mathrm{L}^{-1}$ cellobiose instead of glucose in YPD medium), and YPDX (6.67 $\mathrm{g} \mathrm{L}^{-1}$ glucose and $13.33 \mathrm{~g} \mathrm{~L}^{-1}$ xylose instead of the sugar in YPD medium) was generated at $30{ }^{\circ} \mathrm{C}$ for $24 \mathrm{~h}$ with shaking at $250 \mathrm{rpm}$. During fermentation, the optical density at $600 \mathrm{~nm}\left(\mathrm{OD}_{600}\right)$ was measured by spectrophotometry every $2 \mathrm{~h}$.

\section{Measurement of Reducing Sugar}

The reducing sugar was assayed by the 3,5-dinitrosalicylic acid colorimetric method (DNS method) [12]. Briefly, 1-mL sample was mixed with 3-mL DNS reagent in the colorimetric tube. After boiling for $5 \mathrm{~min}$ in a water bath, the volume was brought to $25 \mathrm{~mL}$ and absorbance was measured at $\mathrm{OD}_{540}$. A standard curve of glucose or xylose was used to determine the reducing sugar concentration. Reducing sugar released from straw and xylitol were determined by HPLC (Agilent 1200) on an Agilent Zorbax Carbohydrate Analysis Column $(4.6 \times 250 \mathrm{~mm}, 5 \mu \mathrm{m})$. All tests were done in triplicate.

\section{Taxonomic Identification and Phylogenetic Analysis}

The selected yeast strain was identified by determining the sequences of the D1/D2 domain of the 26S rDNA. The partial 26S rDNA sequence was PCR amplified using primers NL-1 and NL-4 [16]. The PCR product was separated by agarose gel electrophoresis, then purified with a PCR Clean-up Kit (Axygen, Hangzhou, China) and sequenced at Invitrogen (Shanghai, China). The sequence was compared against the GenBank database (www.ncbi.nlm. nih.gov) and the new 26S rDNA sequence was deposited under accession number KF792071. The sequence of the 26S rDNA D1/D2 domain was aligned with the sequences 
of xylose-fermenting yeast strains retrieved from $\mathrm{NCBI}$ and the resulting tree was plotted using MEGA5 [35].

\section{Morphological and Physiological Characterization}

The macroscopic morphology of yeast grown on YPD or cornmeal agar plate for 1 or 5 days was observed under a general microscope. Growth at different temperatures $(30,37,42$, and $45^{\circ} \mathrm{C}$ ) was performed in YPX medium for $48 \mathrm{~h}$ with shaking and measured as $\mathrm{OD}_{600}$. Sugar utilization tests were carried out using basal medium $\left(5 \mathrm{~g} \mathrm{~L}^{-1}\right.$ peptone and $3 \mathrm{~g} \mathrm{~L}^{-1}$ yeast extract, $\mathrm{pH} 5$ ) plus $20 \mathrm{~g} \mathrm{~L}^{-1}$ sugar (including D-galactose, maltose, sucrose, D-cellobiose, Draffinose, lactose, L-arabinose, D-glucose, D-mannose, D-trehalose, and D-xylose). Cells were cultured in a flask at $30^{\circ} \mathrm{C}$ for $48 \mathrm{~h}$ with shaking. Total crude protein content was estimated from the total nitrogen content by the Kjeldahl method [19].

\section{Optimization of Nitrogen Source for Cell Growth}

Nitrogen source selection was optimized by fractional factorial design as described previously [20]. $\mathrm{NH}_{4} \mathrm{NO}_{3}, \mathrm{NH}_{4} \mathrm{Cl},\left(\mathrm{NH}_{4}\right)_{2} \mathrm{SO}_{4},\left(\mathrm{NH}_{4}\right)_{2} \mathrm{HPO}_{4}$, and urea were added to $\mathrm{XYNB}$ medium (30 $\mathrm{g} \mathrm{L}^{-1}$ xylose, $3.4 \mathrm{~g} \mathrm{~L}^{-1} \mathrm{YNB}$ ). The $\mathrm{C}: \mathrm{N}$ ratio was set to $12: 1$ by bringing each nitrogen source to a concentration of $1.42,1.91,2.36,2.36$, and $1.07 \mathrm{~g} \mathrm{~L}^{-1}$, respectively. The fractional factorial design is shown in Table 4. Cells were inoculated in flasks and shaken at $250 \mathrm{rpm}$ and $30{ }^{\circ} \mathrm{C}$ for $48 \mathrm{~h}$. Dry cell weight and yields were calculated in triplicate experiments. Experimental design and statistical analyses were performed in Minitab statistical software (Minitab17).

\section{Continuous Feeding Fermentation for Yeast Cells Using Corncob Acid Hydrolysate}

The corncob was dried at $60{ }^{\circ} \mathrm{C}$ to a constant weight and then hydrolysed at $121{ }^{\circ} \mathrm{C}$ for $90 \mathrm{~min}$ using $1 \%$ sulphuric acid with a liquid/solid ratio of 8 . The hydrolysate was filtered and adjusted to $\mathrm{pH}$ 5.0. The inoculum seed culture of $C$. intermedia strain FL023 was grown in YPD medium with constant shaking $(250 \mathrm{rpm})$ at $30{ }^{\circ} \mathrm{C}$ until an $\mathrm{OD}_{600}$ of 20 was reached. Seed culture $(0.3 \mathrm{~L})$ was added to a $10-\mathrm{L}$ automatic continuous-feeding fermenter (DRS71S6, SEW Eurodrive, USA) containing $3 \mathrm{~L}$ of the corncob hydrolysate medium $\left(20 \mathrm{~g} \mathrm{~L}^{-1}\right.$ reducing sugar, $3.4 \mathrm{~g} \mathrm{~L}^{-1} \mathrm{YNB}$, and $2 \mathrm{~g} \mathrm{~L}^{-1} \mathrm{KH}_{2} \mathrm{PO}_{4}$ ). The reactor was agitated at $250 \mathrm{rpm}$ and aeration was maintained at $2 \mathrm{vvm}$. After fermentation for $12 \mathrm{~h}$, fresh concentrated hydrolyte feed medium (160 $\mathrm{g} \mathrm{L}^{-1}$ reducing sugar, $2 \mathrm{~g} \mathrm{~L}^{-1} \mathrm{KH}_{2} \mathrm{PO}_{4}$, and $20 \mathrm{~g} \mathrm{~L}^{-1}$ urea) was added at

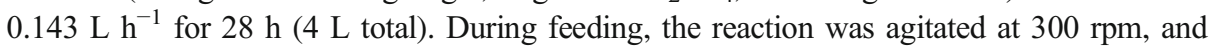
aeration maintained at $3.0 \mathrm{vvm}$. Throughout fermentation, the $\mathrm{pH}$ was maintained at 5.0 by automatic feeding of ammonia. Reducing sugar concentration and dry cell weight per liter culture were determined during fermentation.

\section{Simultaneous Saccharification and Fermentation Production of Yeast Cells with Miscanthus Straw Substrate}

C. intermedia strain FL023 was grown at $30{ }^{\circ} \mathrm{C}$ in YPX medium. At $\mathrm{OD}_{600}=20$, cells were used for inoculation. Miscanthus straw (50 $\mathrm{g} \mathrm{L}^{-1}, 100$ mesh) pretreated with $1.25 \mathrm{M} \mathrm{NaOH}$ and each nitrogen source $\left[10 \mathrm{~g} \mathrm{~L}^{-1}\right.$ yeast extract; or $10 \mathrm{~g} \mathrm{~L}^{-1}$ corn steep liquor (CSL), $0.64 \mathrm{~g} \mathrm{~L}^{-1}$, urea and $1.41 \mathrm{~g} \mathrm{~L}^{-1}\left(\mathrm{NH}_{4}\right)_{2} \mathrm{SO}_{4}$ corresponding to the same amounts of nitrogen 
of $10 \mathrm{~g} \mathrm{~L}^{-1}$ yeast extract] was mixed with $\mathrm{H}_{2} \mathrm{O}$ up to $40 \mathrm{~mL}$ in a $500-\mathrm{mL}$ flask, adjusted to $\mathrm{pH} 5.0$, and autoclaved at $115{ }^{\circ} \mathrm{C}$ for $20 \mathrm{~min}$. After cooling the autoclaved suspension of cellulosic material, $10 \%(v / v, 5 \mathrm{~mL})$ yeast starter culture $\left(1 \times 10^{9} \mathrm{~mL}^{-1}\right)$ and 10 filter paper units (FPU) per gram substrate of cellulase (Celic2, Novozymes, Denmark) were added up to $50 \mathrm{~mL}$ medium for simultaneous saccharification and fermentation (SSF). The cell culture was incubated at $30{ }^{\circ} \mathrm{C}$ with shaking for $72 \mathrm{~h}$. Cell numbers were quantified by viable counting and reducing sugars were measured by HPLC.

\section{Shaking-Flask Fermentation for Xylitol}

C. intermedia strain FL023 was pregrown overnight in rich nutrition medium containing $20 \mathrm{~g} \mathrm{~L}^{-1}$ xylose, $20 \mathrm{~g} \mathrm{~L}^{-1}$ peptone, and $10 \mathrm{~g} \mathrm{~L}^{-1}$ yeast extract. After that, cells were collected, washed twice with water, and resuspended in xylose medium $\left(5 \mathrm{~g} \mathrm{~L}^{-1}\right.$ peptone, $3 \mathrm{~g} \mathrm{~L}^{-1}$ yeast extract and xylose) for fermentation. The fermentation process was conducted through two stages: aerobic cell growth and microaerobic xylitol production. For aerobic growth, the strain was inoculated for $12 \mathrm{~h}$ at $30{ }^{\circ} \mathrm{C}$ with a starting $\mathrm{OD}_{600}$ of 1.0 at $240 \mathrm{rpm}$; for microaerobic xylitol production, fermentation was carried out for $72 \mathrm{~h}$ at $140 \mathrm{rpm}$ and $30{ }^{\circ} \mathrm{C}$. To test the inhibitor tolerance, cells were cultured in xylose medium with $0.5 \mathrm{~g} \mathrm{~L}^{-1}$ furfural, acetic acid, or syringaldehyde, respectively. One-milliliter samples were removed at the indicated time points to test the growth of the culture by spectrophotometer and $50 \mu \mathrm{L}$ supernatants were analyzed to determine xylose and xylitol concentrations by HPLC.

\section{Production of Xylitol from Xylose in a 5-L Bioreactor}

$15 \%(v / v)$ seed culture of $C$. intermedia strain FL023 $(300 \mathrm{~mL})$ pregrown overnight in rich nutrition medium containing $20 \mathrm{~g} \mathrm{~L}^{-1}$ xylose, $20 \mathrm{~g} \mathrm{~L}^{-1}$ peptone, and $10 \mathrm{~g} \mathrm{~L}^{-1}$ yeast extract was inoculated in the fermentation medium containing $80 \mathrm{~g} \mathrm{~L}^{-1}$ xylose and $10 \mathrm{~g} \mathrm{~L}^{-1}$ corn steep liquor (CSL) in $2 \mathrm{~L}$ working volume. Aerobic cell growth at $30{ }^{\circ} \mathrm{C}$ for $24 \mathrm{~h}$ at $240 \mathrm{rpm}$ with aeration of $0.6 \mathrm{vvm}$ and sequential microaerobic xylitol production at $30{ }^{\circ} \mathrm{C}$ for $96 \mathrm{~h}$ at $140 \mathrm{rpm}$ with aeration of $0.4 \mathrm{vvm}$ were conducted in this study. To test the rate of production of xylitol and the growth of cells, 2-mL samples were removed at the indicated time points. The culture was tested by spectrophotometer at OD $600 \mathrm{~nm}$ and $50 \mu \mathrm{L}$ supernatant was dissolved in dilute sulphuric acid to analyze xylose and xylitol concentrations by HPLC.

\section{Statistical Analysis}

All experiments were conducted in triplicate. Data were analyzed using Excel and the mean \pm SD were calculated. Experimental design and statistical analyses for optimization of nitrogen sources were performed in Minitab statistical software (Minitab17).

\section{Results}

\section{Isolation of a High-Efficiency Xylose-Utilization Yeast Strain}

Cellulosic hydrolysates consist of 600-700 $\mathrm{g} \mathrm{kg}^{-1}$ glucose and 300-400 $\mathrm{g} \mathrm{kg}^{-1}$ xylose [26]. However, inefficient xylose usage is the main obstacle to exploring lignocellulose resources. 
Six previously isolated yeast strains were screened for high-efficiency xylose utilization. All strains were cultured in YPX medium at $30{ }^{\circ} \mathrm{C}$ and $250 \mathrm{rpm}$ for $48 \mathrm{~h}$. Under these conditions, ethanol fermentation was inhibited and most of the sugar was used for cell growth. As shown in Table 1, cell number, dry cell weight, and yields of strain FL023 were the highest; Y28 and Y7 had the lowest yields. Thus, as judged by all three parameters, the strain FL023 was better than the other candidate strains and was selected for further study. Growth of FL023 was assessed in glucose, xylose, cellobiose, and glucose-xylose media. FL023 grew quickly in all tested media; the $\mathrm{OD}_{600}$ reached 25 at stationary phase (Fig. 1). It showed average productivities of 0.21 , $0.22,0.21$, and $0.25 \mathrm{~g} \mathrm{~L}^{-1} \mathrm{~h}^{-1}$, and yields of $0.38,0.39,0.40$, and $0.44 \mathrm{~g} \mathrm{~g}^{-1}$ in glucose, xylose, cellobiose, and mixed-sugar media. FL023 grew faster in glucose medium during exponential phase and had a longer lag phase in xylose medium than that in glucose medium. Xylose, one of the major sugar in lignocellulose hydrolysates, was quickly consumed at the first $25 \mathrm{~h}$. Importantly, cellobiose, one of the main factors in feedback inhibition of cellulose hydrolysis, was quickly assimilated by FL023 (Fig. 1). All these results suggested the strain FL023 has great potential in SCP production using the lignocellulose as the carbon source.

\section{Taxonomic Identification and Phylogenetic Analysis}

The sequence of the D1/D2 domain of the 26S rDNA from the strain FL023 (NCBI accession number, KF792071) was amplified and searched against the NCBI database. The sequence was most similar to Candida intermedia strain VVT C-04520 (NCBI accession, DQ377635) [17]. Thus, the strain was named C. intermedia FL023. Differences between strain FL023 and strain VVT C-04520 included six substitutions in the 558 nucleotides (98.9\% identity) in the D1/D2 domain of the 26S rDNA sequence. According to previous studies, Candida strains with $>1 \%$ nucleotide substitutions in the D1/D2 domain likely represent different species [16]. Thus, strain FL023 represents a novel $C$. intermedia species. The phylogenetic tree of $26 \mathrm{~S}$ rDNA D1/D2 sequences is shown in Fig. 2. C. intermedia FL023 formed a close lineage with all Candida species except $C$. intermedia strain GDB 805, C. intermedia isolate P-23, and C. pseudointermedia strain PH-M6 (bootstrap value 86\%).

\section{Morphological and Physiological Characterization}

The physiological characteristics of $C$. intermedia FL023 are summarized in Table 2. The optimal $\mathrm{pH}$ for growth of strain FL023 was 5.0 in YPD medium; the strain grew at $\mathrm{pH}$ 4.4-7.6, formed a pulvinate, smooth, ivory-white colony on YPD agar, and did not become dry or wrinkled. The strain grew well at 28 and $30^{\circ} \mathrm{C}$ and grew weakly at $37^{\circ} \mathrm{C}$ in YPD and YPX media. It assimilated

Table 1 Screening for efficient pentose-assimilation yeast strain

\begin{tabular}{llll}
\hline Strains & $\begin{array}{l}\text { Viable count } \\
\left(\times 10^{9} \mathrm{cfu} \mathrm{mL}^{-1}\right)\end{array}$ & $\begin{array}{l}\text { Cell dry } \\
\text { weight }\left(\mathrm{g} \mathrm{L}^{-1}\right)\end{array}$ & $\begin{array}{l}\text { Yield } \\
\left(\mathrm{g} \mathrm{g}^{-1}\right)\end{array}$ \\
\hline FL023 & 1.26 & 8.1 & 0.40 \\
FL621 & 0.44 & 3.1 & 0.16 \\
Y3 & 0.51 & 3.4 & 0.17 \\
Y7 & 0.52 & 3.3 & 0.17 \\
Y10 & 0.58 & 5.4 & 0.27 \\
Y28 & 0.66 & 4.4 & 0.22 \\
\hline
\end{tabular}


Fig. 1 Growth curve of C. intermedia FL023 in $20 \mathrm{~g} \mathrm{~L}^{-1}$ glucose, xylose, cellobiose, and mixed sugar $\left(6.67 \mathrm{~g} \mathrm{~L}^{-1}\right.$ glucose and $13.33 \mathrm{~g} \mathrm{~L}^{-1}$ xylose) media

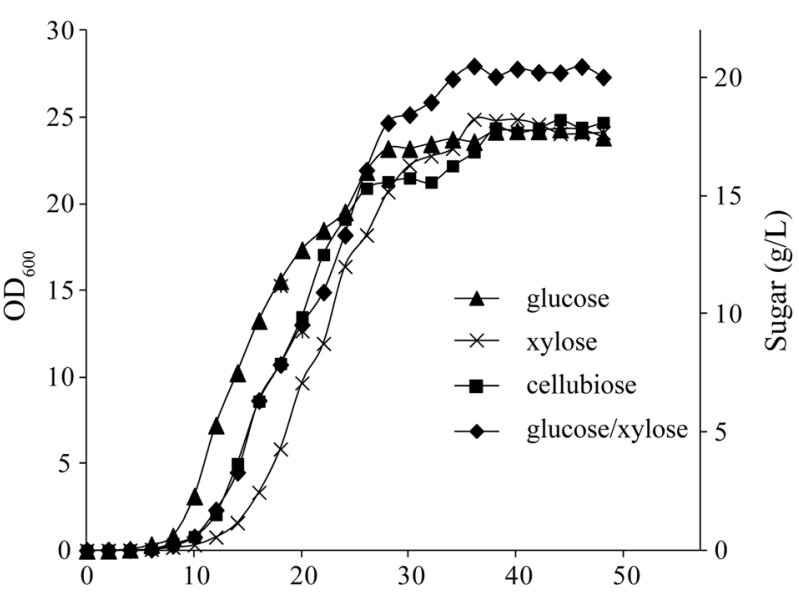

all tested sugars well, except D-galactose, $\alpha$-lactose, and L-arabinose. FL023 was not able to produce ethanol from xylose. Microscopic observation of FL023 grown on YPD medium revealed that the strain was ellipsoidal in shape, ranging from 3.5-5.5 $\mu \mathrm{M}$ at large diameter and 2.9-4.5 $\mu \mathrm{M}$ at small diameter, proliferated by budding, and produced oval cells in a chain of elongated cells. However, pseudohyphae were not observed on YPD or cornmeal agar plates. Strain FL023 showed higher tolerance against $\mathrm{NaCl}$ (Table 2). This strain contained $48.4 \%$ crude proteins based on total nitrogen measurement. The dry cell weight of strain FL023 sample is correlated to either the $\mathrm{OD}_{600}$ or the number of cells per volume. It was estimated that $\mathrm{OD}_{600}=1$ was equivalent to $0.31 \mathrm{~g} \mathrm{~L}^{-1}$, and $10^{9}$ cells $\mathrm{mL}^{-1}$ was equivalent to $0.65 \mathrm{~g}$ of dried cells per liter. It could therefore be used to estimate cell mass production during SSF.

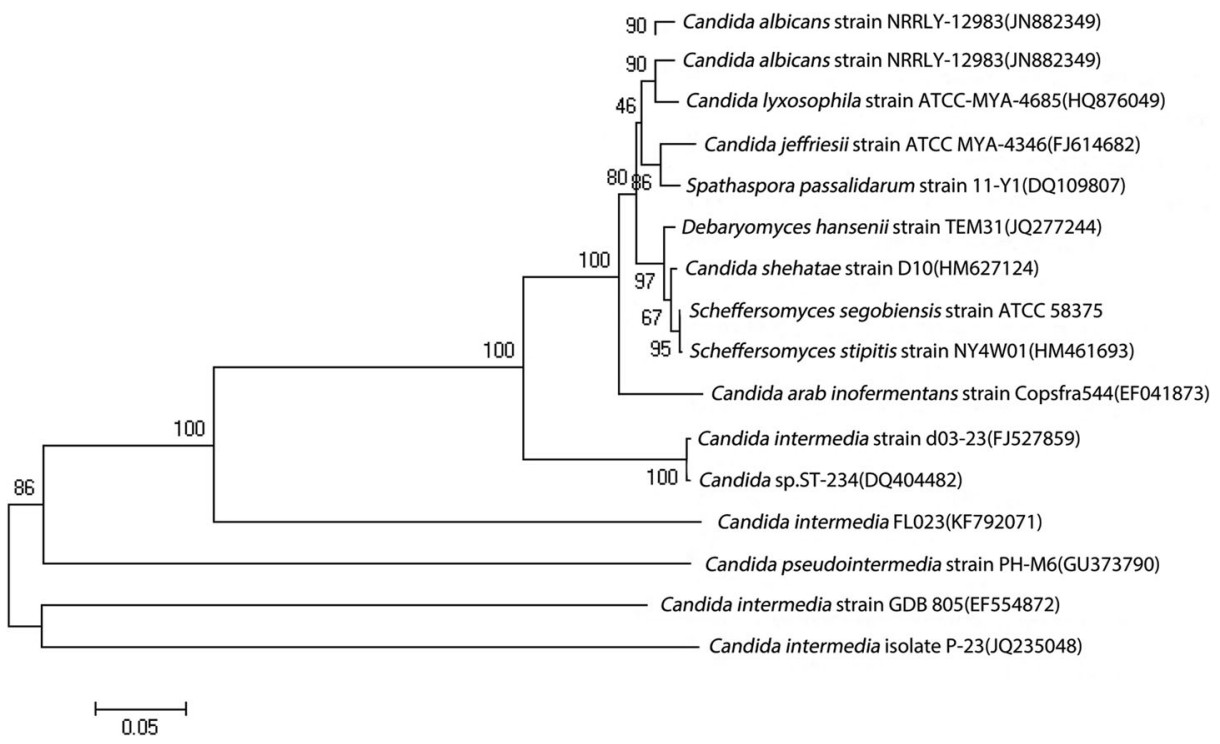

Fig. 2 Phylogenetic tree generated by neighbor-joining analysis based on the D1/D2 region of the 26S rDNA sequence of $C$. intermedia FL023 and pentose-assimilating yeast. Numbers on the branches represent bootstrap values; accession numbers for the $26 \mathrm{~S}$ rDNA sequences follow the strain names 


\section{Inorganic Nitrogen Source Optimization}

A fractional factorial design was used to find the best nitrogen resource for optimal xylose conversion. Five low-cost nitrogen resources [urea, $\mathrm{NH}_{4} \mathrm{NO}_{3}, \mathrm{NH}_{4} \mathrm{Cl},\left(\mathrm{NH}_{4}\right)_{2} \mathrm{SO}_{4}$, and $\left.\left(\mathrm{NH}_{4}\right)_{2} \mathrm{HPO}_{4}\right]$ were used in this experiment. The medium consisted of $20 \mathrm{~g} \mathrm{~L}^{-1}$ xylose and each nitrogen source (the mass ratio of $\mathrm{C}: \mathrm{N}$ is 12:1). The fractional factorial design and results are shown in Table 3. The significance analysis was performed in Minitab statistical software (Minitab17; Table 4). Urea significantly improved xylose conversion $(p=0.019)$. $\left(\mathrm{NH}_{4}\right)_{2} \mathrm{SO}_{4}$ had a slightly positive effect (Table 4). Other nitrogen sources had a negative effect on xylose conversion; thus, urea was selected as the nitrogen source for fermentation of corncob hydrolysate and Miscanthus straw.

\section{Efficient Transformation of Corncob Hydrolysate into Yeast Cells}

Fermentation was performed at $30{ }^{\circ} \mathrm{C}$ for $40 \mathrm{~h}$ with aeration at $2.0 \mathrm{vvm}$ with corncob acid hydrolysate and urea as the carbon and nitrogen sources. The starter culture contained 3-L medium (6.71 $\mathrm{g} \mathrm{L}^{-1}$ glucose and $13.29 \mathrm{~g} \mathrm{~L}^{-1}$ xylose), and the continuous feeding medium contained $4 \mathrm{~L}$ concentrated corncob acid hydrolysate $\left(160 \mathrm{~g} \mathrm{~L}^{-1}\right.$ reducing sugar) and $20 \mathrm{~g} \mathrm{~L}^{-1}$ urea (Fig. 3). This method yielded average sugar and urea concentrations of 86.14 and $11.32 \mathrm{~g} \mathrm{~L}^{-1}$. Reducing sugar was assimilated quickly; at $12 \mathrm{~h}$, continuous feeding with sugar was initiated. The sugar concentration slightly increased after feeding until $19 \mathrm{~h}$, after which the concentration dropped quickly. After $25 \mathrm{~h}$, the sugar was nearly depleted; cell mass increased throughout the process and finally reached $\mathrm{OD}_{600}$ of 35 , which was equal to $34.6 \mathrm{~g} \mathrm{~L}^{-1}$ (Fig. 3). The productivity was $0.86 \mathrm{~g} \mathrm{~L}^{-1} \mathrm{~h}^{-1}$ and yield was $0.40 \mathrm{~g} \mathrm{~g}^{-1}$.

\section{Efficient Transformation of Miscanthus Straw into Yeast Cells}

Miscanthus has been identified as a biomass crop with global potential [21]. However, lignocellulose has been designed by nature to resist degradation [8]. Steam pretreatment with dilute mineral acids is an efficient approach to depolymerizing hemicellulose (200$400 \mathrm{~g} \mathrm{~kg}^{-1}$ of biomass dry weight) into sugars (hemicellulose hydrolysate, primarily

Table 2 Phenotypic characteristics of Candida intermedia FL023

\begin{tabular}{|c|c|c|c|c|c|}
\hline Spore formation & - & & & & \\
\hline Pseudohyphae formation & - & & & & \\
\hline Ethanol fermentation & w & & & & \\
\hline \multicolumn{6}{|l|}{ Assimilation } \\
\hline D-glucose & +++ & D-xylose & +++ & D-galactose & ++ \\
\hline L-arabinose & + & Sucrose & +++ & D-trehalose & ++ \\
\hline maltose & +++ & $\alpha$-lactose & ++ & D-cellobiose & +++ \\
\hline D-raffinose & +++ & & & & \\
\hline \multicolumn{6}{|l|}{ Growth temperature } \\
\hline $28^{\circ} \mathrm{C}$ & +++ & $30{ }^{\circ} \mathrm{C}$ & +++ & & \\
\hline $37^{\circ} \mathrm{C}$ & w & $40{ }^{\circ} \mathrm{C}$ & - & & \\
\hline \multicolumn{6}{|l|}{$\mathrm{NaCl}$ tolerance } \\
\hline $12 \%$ & +++ & $14 \%$ & +++ & & \\
\hline $16 \%$ & $\mathrm{w}$ & $18 \%$ & w & & \\
\hline
\end{tabular}

Positive,,++++++ ; - negative; w weak 
Table 3 Fractional factorial design for optimal nitrogen source for C. intermedia growth

\begin{tabular}{llllllll}
\hline No. & Urea & $\mathrm{NH}_{4} \mathrm{NO}_{3}$ & $\mathrm{NH}_{4} \mathrm{Cl}$ & $\left(\mathrm{NH}_{4}\right)_{2} \mathrm{SO}_{4}$ & $\left(\mathrm{NH}_{4}\right)_{2} \mathrm{HPO} 4$ & $\begin{array}{l}\text { Dry cell } \\
\text { weight }\left(\mathrm{g} \mathrm{L}^{-1}\right)\end{array}$ & Yield \\
\hline 1 & 1.071 & 0.000 & 0.000 & 0.000 & 0.000 & 7.00 & $0.2345 \pm 0.02$ \\
2 & 0.000 & 0.000 & 1.911 & 2.357 & 0.000 & 4.00 & $0.1741 \pm 0.04$ \\
3 & 1.071 & 1.42 & 0.000 & 2.357 & 0.000 & 6.50 & $0.2223 \pm 0.03$ \\
4 & 0.000 & 0.000 & 0.000 & 2.357 & 2.357 & 4.5 & $0.1749 \pm 0.03$ \\
5 & 1.071 & 0.000 & 1.911 & 0.000 & 2.357 & 5.75 & $0.1951 \pm 0.01$ \\
6 & 1.071 & 1.420 & 1.911 & 2.357 & 2.357 & 5.5 & $0.1860 \pm 0.05$ \\
7 & 0.000 & 1.420 & 1.911 & 0.000 & 0.000 & 4.25 & $0.1443 \pm 0.03$ \\
8 & 0.000 & 1.420 & 0.000 & 0.000 & 2.357 & 5.00 & $0.1696 \pm 0.01$ \\
\hline
\end{tabular}

xylose) and to increase access of cellulase enzymes [8]. However, side reaction products (furfural, 5-hydroxymethylfurfural, formate, acetate, and soluble lignin products) formed during pretreatment hinder fermentation [22]. In contrast, SSF enables fermentation of lignocellulose [28].

The SSF process for SCP production from Miscanthus straw substrate was used in this study. Prior to SSF, the straw was crushed to 100 -mesh size (average $150 \mu \mathrm{m}$ ) and pretreated with $1.5 \mathrm{M} \mathrm{NaOH}$. SSF was performed at $30^{\circ} \mathrm{C}$ for $72 \mathrm{~h}$ in fermentation medium containing $50 \mathrm{~g} \mathrm{~L}^{-1}$ pretreated Miscanthus straw, $10 \mathrm{~g} \mathrm{~L}^{-1}$ yeast extract [or $0.64 \mathrm{~g} \mathrm{~L}^{-1}$ urea, $1.41 \mathrm{~g} \mathrm{~L}^{-1}$ $\left(\mathrm{NH}_{4}\right)_{2} \mathrm{SO}_{4}$, or $10 \mathrm{~g} \mathrm{~L}^{-1} \mathrm{CSL}$ ], and $10 \mathrm{FPU} \mathrm{g}^{-1}$ substrate cellulase (Cellic2) in a total volume of $100 \mathrm{~mL}$. With yeast and CSL as the organic nitrogen resources, the cell masses were $13.6 \times 10^{9} \mathrm{~mL}^{-1}$, equal to $8.4 \mathrm{~g}$ dry cell $\mathrm{L}^{-1}$ culture (Fig. $4 \mathrm{a}$ ). Cell masses were $8.6 \times 10^{9} \mathrm{~mL}^{-1}$ and $2.2 \times 10^{9} \mathrm{~mL}^{-1}$, equal to $5.6 \mathrm{~g}$ and $2.1 \mathrm{~g}$ dry cell $\mathrm{L}^{-1}$ culture in media containing urea and $\left(\mathrm{NH}_{4}\right)_{2} \mathrm{SO}_{4}$. Productivity was $0.23,0.23,0.16$, and $0.06 \mathrm{~g} \mathrm{~L}^{-1} \mathrm{~h}^{-1}$ with yields of $0.17,0.17$, 0.11 , and $0.04 \mathrm{~g} \mathrm{~g}^{-1}$ in media containing yeast extract, CSL, urea, and $\left(\mathrm{NH}_{4}\right)_{2} \mathrm{SO}_{4}$, respectively. Although urea was the best nitrogen source in corncob hydrolysate fermentation, it was not suitable in SSF; the cost-effective alternative CSL worked well. Furthermore, cell mass accumulation and reducing sugar release were monitored during fermentation of Miscanthus straw and CSL (Fig. 4b). Throughout the process, sugar (glucose and xylose) released from Miscanthus straw remained low in broth, and cell mass accumulated quickly. Cell mass productivity was at its greatest in the first $10 \mathrm{~h}$ and slowed thereafter, at which time xylose assimilation might accelerate from 10 to $20 \mathrm{~h}$. A similar relationship was observed between cell mass productivity and xylose assimilation throughout the process, suggesting catabolite repression was the main hindrance to productivity.

Table 4 Significant analysis of optimal nitrogen sources for production of yeast cells

\begin{tabular}{|c|c|c|c|c|}
\hline Argument & Coefficient & $\begin{array}{l}\text { Standard error of } \\
\text { regression coefficient }\end{array}$ & $T$ & $p$ \\
\hline Constant & 0.189975 & 0.007561 & 25.12 & 0.002 \\
\hline Urea & 0.040850 & 0.005765 & 7.09 & $0.019 *$ \\
\hline $\mathrm{NH}_{4} \mathrm{NO}_{3}$ & -0.009930 & 0.004348 & -2.28 & 0.150 \\
\hline $\mathrm{NH} 4 \mathrm{Cl}$ & -0.013318 & 0.003231 & -4.12 & 0.054 \\
\hline$(\mathrm{NH} 4)_{2} \mathrm{SO}_{4}$ & 0.001464 & 0.002619 & 0.56 & 0.633 \\
\hline$(\mathrm{NH} 4)_{2} \mathrm{HPO}_{3}$ & -0.005261 & 0.002619 & -2.01 & 0.182 \\
\hline
\end{tabular}

$* p$ value $<0.05$ means an efficient improvement to the yield 
Fig. 3 C. intermedia FL023 growth in corncob acid hydrolysate by continuous fedbatch fermentation. Nitrogen source, $20 \mathrm{~g} \mathrm{~L}^{-1}$ urea. Continuous feeding began at $12 \mathrm{~h}$

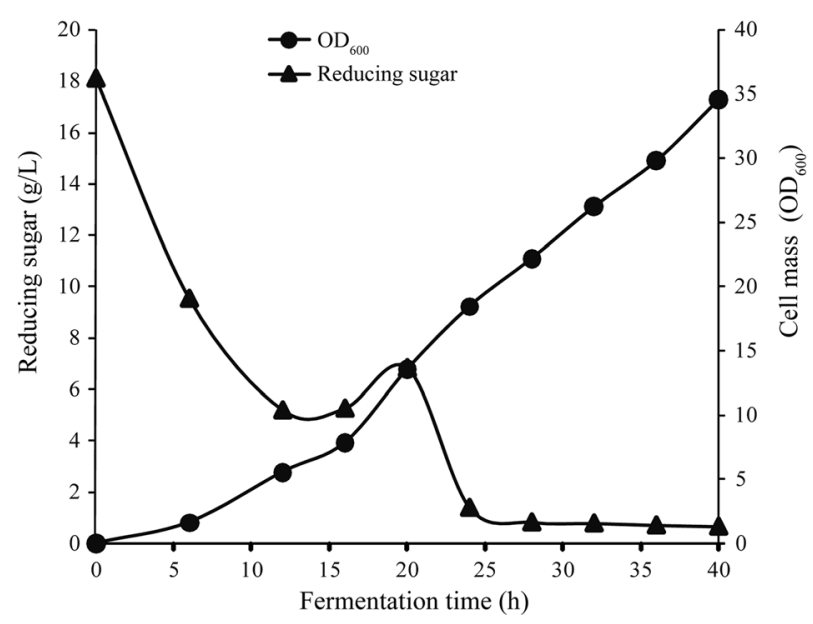

\section{Xylitol Production and Inhibitor Tolerance}

C. intermedia FL023 produces little ethanol from xylose and accumulates xylitol in the medium. At the flask level, $27.1 \mathrm{~g} \mathrm{~L}^{-1}$ xylitol was produced the medium containing $80 \mathrm{~g} \mathrm{~L}^{-1}$ xylose (Fig. 5a); while more xylitol (34.6 $\mathrm{g} \mathrm{L}^{-1}$ ) was produced from the medium containing $120 \mathrm{~g} \mathrm{~L}^{-1}$ xylose (Fig. 5b). However, at these conditions, only 35.8 and $37.8 \mathrm{~g} \mathrm{~L}^{-1}$ xylose were consumed (Fig. 5a and b). These results indicated that xylose-to-xylitol transformation efficiency was high $\left(0.76\right.$ and $\left.0.92 \mathrm{~g} \mathrm{~g}^{-1}\right)$; however, the xylitol productivities were very low. Increasing the xylose concentration to $200 \mathrm{~g} \mathrm{~L}^{-1}$ in the medium, however, reduced the xylitol titer to $23.6 \mathrm{~g} \mathrm{~L}^{-1}$, indicating high substrate concentration inhibited xylitol production ability significantly of C. intermedia FL023 (Fig. 5c). It is clear that the production rate and productivity of xylitol increased with the increase of initial xylose titer but the conversion efficiency would be reduced if the xylose concentration was too high. This is because xylose reductase (XR) activity is significantly affected by xylose concentration, which would ferment D-xylose into xylitol with NADPH as a cofactor; and excessive xylose increases the osmotic pressure, resulting in substrate inhibition $[5,37,40]$. Therefore, xylitol fermentation with extended time and low initial xylose substrate was conducted in a 5-L bioreactor under a microaerobic condition. At $72 \mathrm{~h}$ in the bioreactor, more xylose was consumed (residual xylose titer 43.0 vs $26.9 \mathrm{~g} \mathrm{~L}^{-1}$, Fig. 5d) and more xylitol was produced (27.1 vs $32.9 \mathrm{~g} \mathrm{~L}^{-1}$, Fig. $5 \mathrm{~d}$ ), indicating strict aeration condition facilitated xylitol fermentation. With extension of fermentation time, xylose was nearly completely consumed at $120 \mathrm{~h}$ with residual xylose of $5.9 \mathrm{~g} \mathrm{~L}^{-1}$. Finally, the xylitol titer, yield, and productivity reached $45.7 \mathrm{~g} \mathrm{~L}^{-1}, 0.57 \mathrm{~g} \mathrm{~g}^{-1}$ xylose, and $0.38 \mathrm{~g} \mathrm{~L}^{-1} \mathrm{~h}^{-1}$. However, the xyloseto-xylitol transformation efficiency was low, and more cell mass was detected (Fig. 5d), indicating a part of xylose was transformed into cell mass and reduced the xylitol yield.

Xylose could be liberated from lignocellulosic materials by hemicellulase; however, pretreatment of lignocellulose, the first step for hydrolysis, generated several kinds of inhibitors. However, pretreatments generate inhibitors (phenolic compounds and formic acid in alkalinepretreated biomass and hydroxymethyl furfural [HMF] and furfural in acid-pretreated biomass) that repress LA fermentation. Inhibitors present in the hydrolysate always repress microorganism growth and fermentation [41]. Thus, the tolerance of $C$. intermedia FL023 to phenolic inhibitors generated by alkaline pretreatment was tested. As shown in Fig. 6, C. intermedia 
Fig. 4 C. intermedia FL023 growth in $50 \mathrm{~g} \mathrm{~L}^{-1} \mathrm{NaOH}$ pretreated Miscanthus straw media under simultaneous saccharification and fermentation (SSF) conditions. Ten filter paper units Cellic2 per gram dry straw was added. a $0.64 \mathrm{~g} \mathrm{~L}^{-1}$ urea, $1.41 \mathrm{~g} \mathrm{~L}^{-1}\left(\mathrm{NH}_{4}\right)_{2} \mathrm{SO}_{4}, 10 \mathrm{~g} \mathrm{~L}^{-1}$ yeast extract (YE), or $10 \mathrm{~g} \mathrm{~L}^{-1}$ corn steep liquor (CSL) served as the nitrogen source. b Cell mass accumulation and reducing sugar release during fermentation using CSL as the nitrogen source
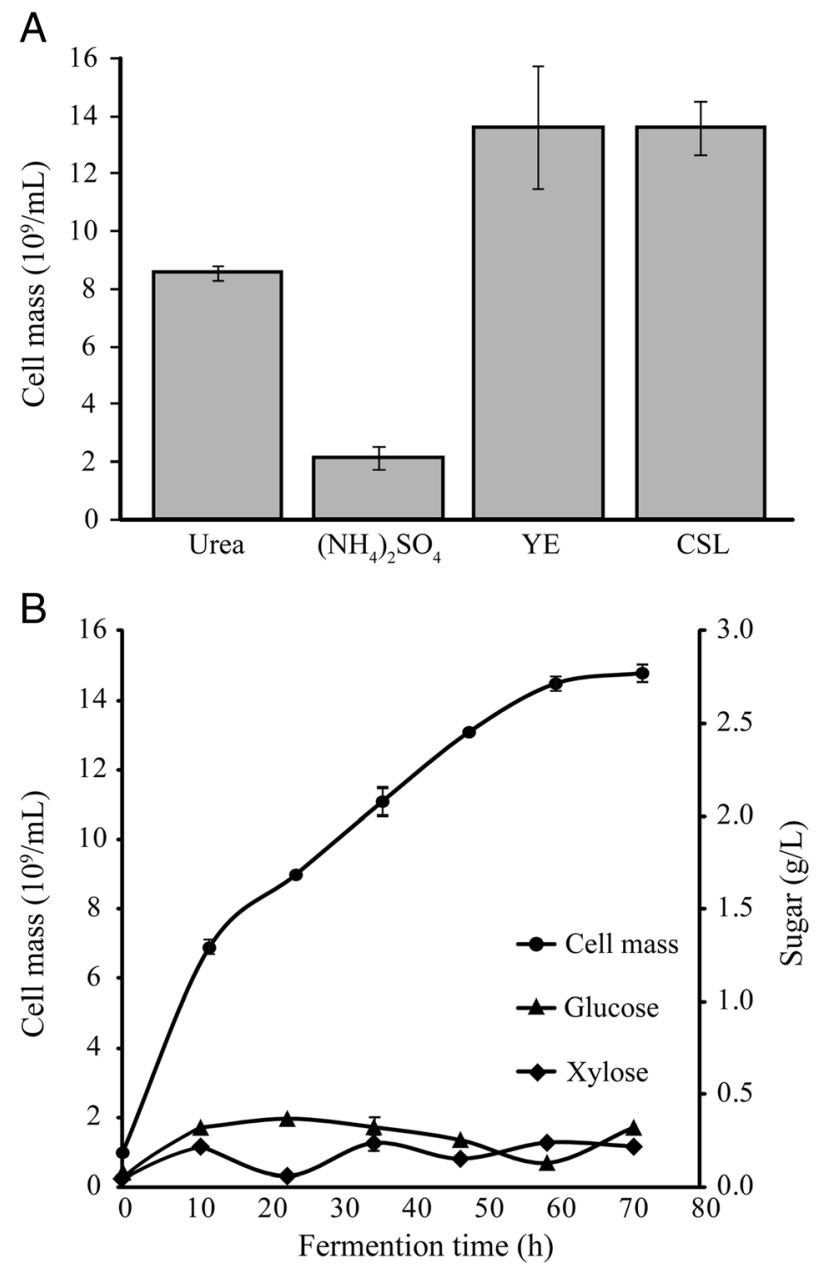

FL023 grew and produced xylitol well from $80 \mathrm{~g} \mathrm{~L}^{-1}$ xylose medium containing $0.5 \mathrm{~g} \mathrm{~L}^{-1}$ of furfural, acetic acid, and syringaldehyde, compared to the control experiment using the fermentation medium containing no inhibitor. Surprisingly, the 1.21-fold higher xylitol yield was achieved by FL023 compared to the furfural-free control medium or acetic acid and syringaldehyde media (Fig. 6). It is probable that dehydrogenation of xylitol produces coenzyme $\mathrm{NADH}$, which promotes the recycling of $\mathrm{NAD}^{+}$and facilitates the reduction of furfural $[38,39]$. Acetic acid and syringaldehyde showed little inhibitory effects on xylitol production by strain FL023. Taking the results together, C. intermedia FL402 showed strong tolerance to the tested inhibitors from pretreatment of lignocellulosic materials.

\section{Discussion}

Lignocellulose is one of the most abundant renewable feedstocks that has attracted considerable attention as a substrate for biofuel and biochemical production. Lignocellulose contains mainly 


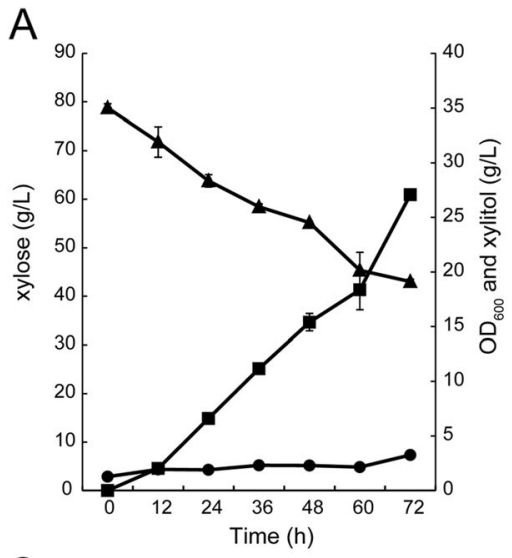

C
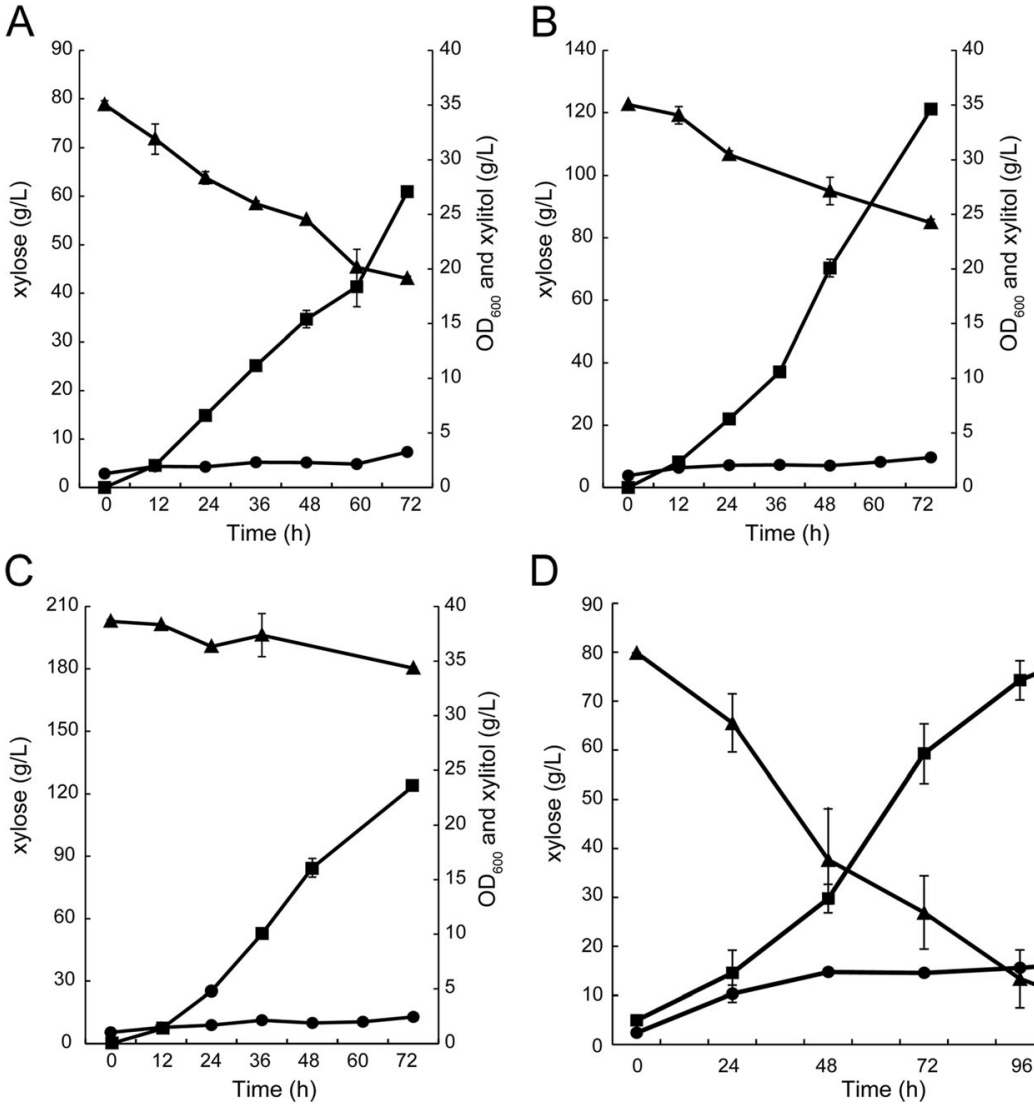

D

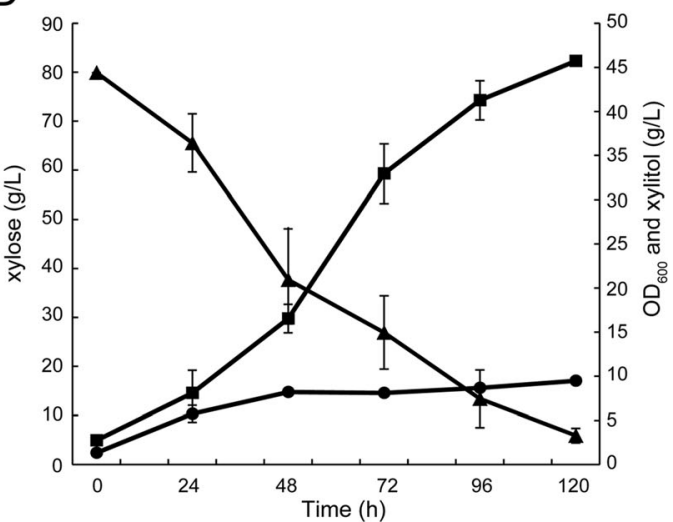

Fig. 5 Xylitol fermentation from xylose in flasks and a 5-L bioreactor. Xylitol fermentation in flasks with a $80 \mathrm{~g} \mathrm{~L}^{-1}$, b 120 , and $\mathbf{c} 200 \mathrm{~g} \mathrm{~L}^{-1}$ xylose at $30^{\circ} \mathrm{C}$; $\mathbf{d}$ xylitol fermentation in a 5-L bioreactor with $80 \mathrm{~g} \mathrm{~L}^{-1}$ xylose as substrate at $30^{\circ} \mathrm{C}$. Triangle, xylose; square, xylitol; and circle, cell density $\left(\mathrm{OD}_{600}\right)$

glucan and xylan that are embedded in a lignin-carbohydrate complex, which cannot be directly utilized by microorganisms. Therefore, three steps including pretreatment, enzymatic hydrolysis, hexose fermentation, and pentose fermentation are required for efficient utilization of lignocellulosic materials for SCP and xylitol production. In this study, we isolated a novel yeast strain C. intermedia FL023 which has a strong ability to utilize both pentose and hexose as well as cellulose, the most serious cellulase inhibitor, for cell growth, indicating this strain is a good candidate for SCP and xylitol, even ethanol production. Because of the high xylose and cellobiose utilization efficiency, the genomic DNA of strain FL023 has been electroporated into a thermotolerant Saccharomyces cerevisiae strain to generate a hybrid yeast strain with both good characteristics from the parental strains [31]. However, we found strain FL023 produced very little ethanol from xylose. Therefore, we focused on studying the SCP and xylitol production from lignocellulosic materials by this yeast strain. First of all, we found urea was the best nitrogen source for SCP production using the corncob hydrolysate as the carbon source through fed-batch separated hydrolysis and fermentation (SHF) process. Cell mass finally reached $\mathrm{OD}_{600}$ of 35 in the fed-batch SHF, which was equal to $34.6 \mathrm{~g} \mathrm{~L}^{-1}$. The productivity and yield were both higher than those previously reported in other yeasts. More importantly, strain FL023 produced $8.4 \mathrm{~g} \mathrm{~L}^{-1}$ dry SCP from Miscanthus straw using CSL as nitrogen source through SSF. C. intermedia FL023 

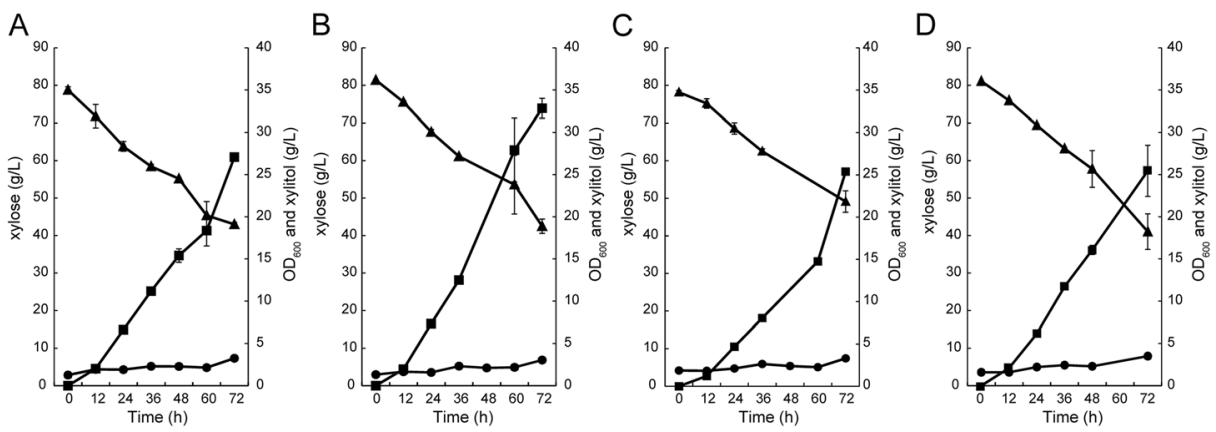

Fig. 6 Inhibitor tolerance of $C$. intermedia FL023 in xylitol fermentation. C. intermedia FL023 was inoculated in xylose medium with a no inhibitor or $0.5 \mathrm{~g} \mathrm{~L}^{-1} \mathbf{b}$ furfural, $\mathbf{c}$ acetate, and $\mathbf{d}$ syringaldehyde. Triangle, xylose; square, xylitol; and circle, cell density $\left(\mathrm{OD}_{600}\right)$

provided a higher SCP yield from straw than ever reported, perhaps because (i) SSF was better than other methods for SCP production from lignocellulose substrate. During SSF, glucose and xylose were continuously released from glucan polymers and hemicellulose by Cellic2; the sugar released by hydrolysis is immediately consumed by the fermenting organisms, thus avoiding product inhibition. (ii) In SSF during the sugar releasing process, the low xylose concentration enhances xylose transport by the high-affinity transporters in Candida [32, 33].

Candida species are good candidates for high-titer and high-yield xylitol production [4]. For examples, C. tropicalis KCTC7221 and Candida sp. 559-9 produced 110 and $173 \mathrm{~g} \mathrm{~L}^{-1}$ xylitol from 150 and $200 \mathrm{~g} \mathrm{~L}^{-1}$ xylose, one of the main sugars liberated from lignocellulosic materials, respectively $[11,14]$. However, other studies reported xylitol fermentations with low titer and yield. Therefore, the xylitol production ability of strain FL023 was tested. Finally, $45.7 \mathrm{~g} \mathrm{~L}^{-1}$ xylitol was produced by strain FL023 through fed-batch fermentation with the yield and productivity of $0.57 \mathrm{~g} \mathrm{~g}^{-1}$ xylose and $0.38 \mathrm{~g} \mathrm{~L}^{-1} \mathrm{~h}^{-1}$, respectively (Fig. 5d). In this study, it was found that xylitol production rate and productivity by strain FL023 increased with the increase of the initial xylose titer but the conversion efficiency was reduced (Fig. 5), due to that xylose reductase (XR) activity is significantly affected by xylose concentration [5, 37, 40]. Therefore, xylitol production through fed-batch fermentation with extended time and moderate concentration of xylose substrate was preferred. We also found that a high rate of xylitol production correlated with high cell density, while the xylitol production rate slowed down with decreasing xylose concentration (Fig. 5d). Moreover, xylitol is secreted by diffusion or passive transport using the concentration gradient across the membrane, which requires a higher intracellular xylitol concentration than that in the medium. In order to keep a higher titer of xylitol in the cells, a high concentration of xylose must be maintained during xylitol fermentation [13]. Therefore, continuous feeding and fermentation (CFF) could be employed to increase xylitol yield and productivity by $C$. intermedia FL023. At the first stage of the CFF process, the cell density should be increased at aerobic condition using glucose medium. Then, at the fermentation stage, xylose should be continuously supplied to maintain at $80 \mathrm{~g} \mathrm{~L}^{-1}$ and cell growth rate should be restricted by strictly controlling the air supply rate. At these conditions, the xylitol yield and productivity could be increased to satisfy industrial requirement.

Lignocellulose, the most abundant global source of biomass, could be used for biofuel and biochemical production. However, the crystalline structure of lignocellulosic biomass results in the major technical obstacle to biofuel and biochemical production. Therefore, pretreatments are required to break down the crystal structure. Pretreatments generate inhibitors (phenolic 
compounds and formic acid in alkaline-pretreated biomass and hydroxymethyl furfural [HMF] and furfural in acid-pretreated biomass) that repress LA fermentation. Thus, efficient LA production from pretreated biomass requires the removal of these inhibitors prior to fermentation or the use of inhibitor-tolerant bacteria. C. intermedia FL402 showed strong tolerance to furfural, acetic acid, and syringaldehyde, which represented the inhibitors from pretreated lignocellulosic materials by acids and alkalines (Fig. 6). This result indicated strain FL023 was feasible for SCP and xylitol production from lignocellulosic hydrolysates through fed-batch SHF or SSF, due to its high tolerance to the inhibitors in the hydrolysates.

Acknowledgements The authors would like to thank the Special Fund for Agro-scientific Research in the Public Interest (No. 201503137) and Fundamental Research Funds for Central Non-profit Scientific Institution (Nos. 1610012017010 and Y2017JC39) for the financial support.

\section{Compliance with Ethical Standards}

Competing Financial Interests The authors declare that they have no competing financial interests.

Open Access This article is distributed under the terms of the Creative Commons Attribution 4.0 International License (http://creativecommons.org/licenses/by/4.0/), which permits unrestricted use, distribution, and reproduction in any medium, provided you give appropriate credit to the original author(s) and the source, provide a link to the Creative Commons license, and indicate if changes were made.

\section{References}

1. Alston, J. M., Beddow, J. M., \& Pardey, P. G. (2009). Agriculture. Agricultural research, productivity, and food prices in the long run. Science, 325, 1209-1210.

2. Anupama and Ravindra, P. (2000). Value-added food: single cell protein. Biotechnology Advance, 18, 459479.

3. Austic, R. E., Mustafa, A., Jung, B., Gatrell, S., \& Lei, X. G. (2013). Potential and limitation of a new defatted diatom microalgal biomass in replacing soybean meal and corn in diets for broiler chickens. Journal of Agricultural and Food Chemistry, 61, 7341-7348.

4. Dasgupta, D., Bandhu, S., Adhikari, D. K., \& Ghosh, D. (2017). Challenges and prospects of xylitol production with whole cell bio-catalysis: a review. Microbiological Research, 197, 9-21.

5. Dasgupta, D., Ghosh, D., Bandhu, S., Agrawal, D., Suman, S. K., \& Adhikari, D. K. (2016). Purification, characterization and molecular docking study of NADPH dependent xylose reductase from thermotolerant Kluyveromyces sp. IIPE453. Process Biochemistry, 51, 124-133.

6. Duarte, L., Carvalheiro, F., Lopes, S., Neves, I., \& Gírio, F. (2008). Yeast biomass production in brewery's spent grains hemicellulosic hydrolyzate. Applied Biochemistry and Biotechnology, 148, 119-129.

7. El-Nawwi, S. A., \& El-Kader, A. A. (1996). Production of single-cell protein and cellulase from sugarcane bagasse: effect of culture factors. Biomass and Bioenergy, 11, 361-364.

8. Girio, F. M., Fonseca, C., Carvalheiro, F., Duarte, L. C., Marques, S., \& Bogel-Lukasik, R. (2010). Hemicelluloses for fuel ethanol: a review. Bioresource Technology, 101, 4775-4800.

9. Gruno, M., Valjamae, P., Pettersson, G., \& Johansson, G. (2004). Inhibition of the Trichoderma reesei cellulases by cellobiose is strongly dependent on the nature of the substrate. Biotechnology and Bioengineering, 86, 503-511.

10. Hecht, V., Rosen, W., \& Schügerl, K. (1985). Conversion of cellulose into fungal cell mass in solid state culture. Applied Microbiology and Biotechnology, 21, 189-191.

11. Ikeuchi, T., Azuma, M., Kato, J., \& Ooshima, H. (1999). Screening of microorganisms for xylitol production and fermentation behavior in high concentrations of xylose. Biomass and Bioenergy, 16, 333339.

12. Imoto, T. (1971). A simple activity measurement of lysozyme. Agricultural and Biological Chemistry, 35, 1154-1156. 
13. Kim, J. H., Han, K. C., Koh, Y. H., Ryu, Y. W., \& Seo, J. H. (2002). Optimization of fed-batch fermentation for xylitol production by Candida tropicalis. Journal of Industrial Microbiolology and Biotechnology, 29, 16-19.

14. Kim, T. B., Lee, Y., Kim, P., Kim, C. S., \& Oh, D. K. (2004). Increased xylitol production rate during longterm cell recycle fermentation of Candida tropicalis. Biotechnology Letters, 26, 623-627.

15. Kogje, A. and Ghosalkar, A. (2016) Xylitol production by Saccharomyces cerevisiae overexpressing different xylose reductases using non-detoxified hemicellulosic hydrolysate of corncob. 3 Biotech, 6, 127.

16. Kurtzman, C. P., \& Robnett, C. J. (1998). Identification and phylogeny of ascomycetous yeasts from analysis of nuclear large subunit (26S) ribosomal DNA partial sequences. Antonie Van Leeuwenhoek, 73, 331-371.

17. Laitila, A., Wilhelmson, A., Kotaviita, E., Olkku, J., Home, S., \& Juvonen, R. (2006). Yeasts in an industrial malting ecosystem. Journal of Industrial Microbiolology and Biotechnology, 33, 953-966.

18. Liu, Z. L., Weber, S. A., Cotta, M. A., \& Li, S. Z. (2012). A new beta-glucosidase producing yeast for lower-cost cellulosic ethanol production from xylose-extracted corncob residues by simultaneous saccharification and fermentation. Bioresource Technology, 104, 410-416.

19. Lynch, J. M., \& Barbano, D. M. (1999). Kjeldahl nitrogen analysis as a reference method for protein determination in dairy products. Journal of AOAC International, 82, 1389-1398.

20. Martinez Cruz, P., Christen, P., \& Farres, A. (1993). Medium optimization by a fractional factorial design for lipase production by Rhizopus delemar. Journal of Fermentation and Bioengineering, 76, 94-97.

21. McKendry, P. (2002). Energy production from biomass (part 1): overview of biomass. Bioresource Technology, 83, 37-46.

22. Mills, T. Y., Sandoval, N. R., \& Gill, R. T. (2009). Cellulosic hydrolysate toxicity and tolerance mechanisms in Escherichia coli. Biotechnology for Biofuels, 2, 26.

23. Mohamad, N. L., Kamal, S. M. M., \& Mokhtar, M. N. (2014). Xylitol biological production: a review of recent studies. Food Reviews International, 31, 74-89.

24. Moo-Young, M., Chahal, D. S., Swan, J. E., \& Robinson, C. W. (1977). SCP production by Chaetomium cellulolyticum, a new thermotolerant cellulolytic fungus. Biotechnology and Bioengineering, 19, 527-538.

25. Moo-Young, M., Chahal, D. S., \& Vlach, D. (1978). Single cell protein from various chemically pretreated wood substrates using Chaetomium cellulolyticum. Biotechnology and Bioengineering, 20, 107-118.

26. Mosier, N., Wyman, C., Dale, B., Elander, R., Lee, Y. Y., Holtzapple, M., \& Ladisch, M. (2005). Features of promising technologies for pretreatment of lignocellulosic biomass. Bioresource Technology, 96, 673-686.

27. Nigam, J. N. (2000). Cultivation of Candida langeronii in sugar cane bagasse hemicellulosic hydrolyzate for the production of single cell protein. World Journal of Microbiology and Biotechnology, 16, 367-372.

28. Öhgren, K., Bura, R., Lesnicki, G., Saddler, J., \& Zacchi, G. (2007). A comparison between simultaneous saccharification and fermentation and separate hydrolysis and fermentation using steam-pretreated corn stover. Process Biochemistry, 42, 834-839.

29. Pandey, A., Soccol, C. R., Nigam, P., Soccol, V. T., Vandenberghe, L. P. S., \& Mohan, R. (2000). Biotechnological potential of agro-industrial residues. II: cassava bagasse. Bioresource Technology, 74, 81-87.

30. Pessoa Jr., A., Mancilha, I. M., \& Sato, S. (1996). Cultivation of Candida tropicalis in sugar cane hemicellulosic hydrolyzate for microbial protein production. Journal of Biotechnology, 51, 83-88.

31. Ren, X., Wang, J., Yu, H., Peng, C., Hu, J., Ruan, Z., Zhao, S., Liang, Y., \& Peng, N. (2016). Anaerobic and sequential aerobic production of high-titer ethanol and single cell protein from $\mathrm{NaOH}$-pretreated corn stover by a genome shuffling-modified Saccharomyces cerevisiae strain. Bioresource Technology, 218, 623-630.

32. Runquist, D., Fonseca, C., Rådström, P., Spencer-Martins, I., \& Hahn-Hägerdal, B. (2009). Expression of the Gxf1 transporter from Candida intermedia improves fermentation performance in recombinant xyloseutilizing Saccharomyces cerevisiae. Applied Microbiology and Biotechnology, 82, 123-130.

33. Runquist, D., Hahn-Hagerdal, B., \& Radstrom, P. (2010). Comparison of heterologous xylose transporters in recombinant Saccharomyces cerevisiae. Biotechnology for Biofuels, 3, 5.

34. Sekita, S., Yoshihira, K., Natori, S., Udagawa, S., Muroi, T., Sugiyama, Y., Kurata, H., \& Umeda, M. (1981). Mycotoxin production by Chaetomium spp. and related fungi. Canadian Journal of Microbiology, 27, 766-772.

35. Tamura, K., Peterson, D., Peterson, N., Stecher, G., Nei, M., \& Kumar, S. (2011). MEGA5: molecular evolutionary genetics analysis using maximum likelihood, evolutionary distance, and maximum parsimony methods. Molecular Biology and Evolution, 28, 2731-2739.

36. van Huis, A. (2013) Potential of insects as food and feed in assuring food security. Annual Review of Entomology, 58, 563-583.

37. Vandeska, E., Amartey, S. A., Kuzmanova, S., \& Jeffries, T. W. (1995). Effects of environmental conditions on production of xylitol by Candida boidinii. World Journal of Microbiology and Biotechnology, 11, 213218. 
38. Wang, S., He, Z., \& Yuan, Q. (2017). Xylose enhances furfural tolerance in Candida tropicalis by improving NADH recycle. Chemical Engineering Science, 158, 37-40.

39. Wang, S., Li, H., Fan, X., Zhang, J., Tang, P., \& Yuan, Q. (2015). Metabolic responses in Candida tropicalis to complex inhibitors during xylitol bioconversion. Fungal Genetics and Biology, 82, 1-8.

40. Wei, N., Quarterman, J., Kim, S. R., Cate, J. H., \& Jin, Y. S. (2013). Enhanced biofuel production through coupled acetic acid and xylose consumption by engineered yeast. Nature Communications, 4, 2580.

41. Zhang, Z., Xie, Y., He, X., Li, X., Hu, J., Ruan, Z., Zhao, S., Peng, N., \& Liang, Y. (2016). Comparison of high-titer lactic acid fermentation from $\mathrm{NaOH}$ - and $\mathrm{NH}_{3}-\mathrm{H}_{2} \mathrm{O}_{2}$-pretreated corncob by Bacillus coagulans using simultaneous saccharification and fermentation. Scientific Reports, 6, 37245.

42. Zheng, Y.-G., Chen, X.-L., \& Wang, Z. (2005). Microbial biomass production from rice straw hydrolysate in airlift bioreactors. Journal of Biotechnology, 118, 413-420. 